\title{
Campylobacter SPECIES IN CHILEAN PATIENTS WITH CHRONIC PERIODONTITIS
}

\author{
ESPÉCIES DE Campylobacter EM PACIENTES CHILENOS COM PERIODONTITE \\ CRONNICA
}

\author{
Hans MONTANARES ${ }^{1}$; Felipe OPAZOㅜㄹ Lilian HERRERA $^{2}$; María Paz VILLANUEVA ${ }^{1}$; \\ Gustavo MEDINA ${ }^{3}$; Heriberto FERNÁNDEZ ${ }^{1} *$ \\ 1. Institute of Clinical Microbiology; 2. Institute of Odontoestomatology; Universidad Austral de Chile, Valdivia, Chile. \\ hfernand@uach.cl; 3. School of Medical Tehcnology, Universidad Católica de Temuco, Temuco, Chile.
}

\begin{abstract}
The purpose of this study is to identify the presence of Campylobacter species $(C$. rectus, $C$. concisus, $C$. gracilis and $C$. ureolyticus) in Chilean patients with chronic periodontitis, and to establish the relationship of these microorganisms with the periodontal conditions of smoker and non-smoker patients. Subgingival plaque samples were collected from four periodontal-affected tissue sites of 15 smoker and 15 non-smoker patients with chronic periodontitis. A sample per quadrant was obtained, with a probing depth of $\geq 6 \mathrm{~mm}$ and an insertion loss of $>3 \mathrm{~mm}$ in each patient. Polymerase chain reaction (PCR) was performed with the specific 16S rDNA primers for the molecular detection of $C$. rectus and $C$. gracilis, specific cpn60 primers for $C$. concisus and hsp60 primers gene for $C$. ureolyticus. Campylobacter species showed an overall prevalence of $93.3 \%$ in periodontal patients, while $C$. rectus was the most frequent one (80\%), followed by C. concisus (66.7\%), C. gracilis (33.3\%), and C. ureolyticus (10\%). Only C. gracilis showed a statistically significant $(p=0.002)$ association with chronic periodontitis among samples from smoker and nonsmoker patients. A high prevalence of the Campylobacter genus in the analyzed populations (93.3\%) was found, being $C$. rectus the most frequent $(80 \%)$ species. Besides, C. gracilis showed a statistically significant association between smoker state and chronic periodontitis.
\end{abstract}

KEYWORDS: Campylobacter. Chronic periodontitis. Smokers. PCR.

\section{INTRODUCTION}

Periodontitis is characterized by the presence of inflammatory lesions in the gingiva, with the formation of a periodontal pocket that leads to the loss of the alveolar bone and, eventually, affecting the tooth itself. The origin of infection of dental tissue is attributed to the accumulation of plaque (PEREZ-CHAPARRO et al., 2014; HENNE et al., 2014). Periodontal diseases are the second most prevalent diseases in the oral cavity. According to the Index of Periodontal Treatment Needs of the Community (GAMONAL et al., 1998), 20 years ago in Chile its prevalence was $90.9 \%$ among the population between 35 to 45 years of age, reaching $100 \%$ in 65 to 74 -years-old people. Also, a recent study conducted in 2016, revealed a high prevalence of periodontitis, reaching more than $80 \%$ among Chilean patients over 18 years old (CARVAJAL, 2016).

The etiology of periodontal diseases is multifactorial, where various factors such as host, environment and infectious agents are involved (PEREZ-CHAPARRO et al., 2014; HENNE et al., 2014; VARGAS SEGURA et al., 2015; SRINIVASAN, 2016; TOMAS et al., 2016; MEURIC et al., 2017). Campylobacter species have been isolated from humans and animals, being also associated with this disease (LASTOVICA, 2016). In humans, several species have been implicated as etiologic agents of periodontal disease (PEREZCHAPARRO et al., 2014, HENNE et al., 2014; VARGAS SEGURA et al., 2015). The Campylobacter species found in the oral cavity associated to oral pathologies are $C$. rectus, $C$. concisus, C. gracilis, C. ureolyticus, C. curvus, $C$. showae and C. sputorum (HENNE et al., 2014; VARGAS SEGURA et al., 2015).

$C$. rectus and $C$. gracilis are the most studied species in periodontal samples and considered to be the most prevalent Campylobacter species in periodontal tissue during disease (HENNE et al., 2014; VARGAS SEGURA et al., 2015). C. concisus was also identified in the oral cavity, being prevalent in biopsies of intestine and feces from patients with chronic gastrointestinal disorders (MUKHOPADHYA et al., 2011; MAHENDRAN et al., 2011; GEMMELL et al., 2017). C. ureolyticus has been detected in the subgingival bacterial plaque. However, it is rarely studied in periodontal disease (DUERDEN et al. 1987; DAHLÉN et al., 2018).

Scientific evidences show that smoking is a risk factor for periodontitis, being active smokers 
more likely to develop more severe periodontal diseases, with higher levels of some of the periodontal microorganisms (BERGSTRÖM, 2003; SHCHIPKOVA et al., 2010; CORETTI et al., 2016).

Having in mind the great diversity and different structure-composition of the subgingival microbiota in chronic periodontitis (TOMAS et al., 2016), the high prevalence of this infectious condition and the scarce information about the different preperiodontopathogens in our country (CARVAJAL, 2016), it seems to be necessary to explore the association of Campylobacter species with chronic periodontitis.

Different molecular methodologies have been used to detect the presence of periodontal bacterial species, which are difficult or even impossible to culture (ERICK; PFISTER, 2002; SRINIVASAN, 2016; MIRA et al., 2017). Using PCR assay, we have attempted to determine the presence of $C$. rectus, $C$. consisus, $C$. gracilis and $C$. ureolyticus in periodontal pockets of Chilean patients with chronic periodontitis, establishing the relationship of the presence of these microorganisms with the pathological conditions of smokers and non-smokers.

\section{MATERIAL AND METHODS}

This is a descriptive cross sectional study, whose target population was adult patients diagnosed with moderate to severe chronic periodontitis at Valdivia city, Chile $\left(39^{\circ} 46^{\prime}\right.$ Southern latitude). Patient selection and sampling, and bacterial identification were carried out at the Dental Clinics and the Institute of Clinical Microbiology of the Universidad Austral de Chile, respectively. The sample size was calculated with the stratified probabilistic method, using the EpiDat 4.2 software, assuming a reference population of 250 patients, an expected frequency of the event under study of $90 \%$, a confidence level of $95 \%$ and an error of 7\% (GAMONAL et al, 1998). This study was approved by the Ethics Committee of the Universidad Austral de Chile.

The participants were adult smokers and non-smokers patients between 35 and 74 years old, who had been clinically and radiographically diagnosed with moderate to severe chronic periodontitis, with no underlying diseases or controlled-underlying diseases. The smoker status was determined in patients who smoked at least 5 cigarettes a day and had been smoking for a minimum of 10 years. Non-smoker patients were those who had never smoked in their lives. This information was gathered through a standardized questionnaire. Any patients who have undergone an antimicrobial therapy, immunosuppressant therapy, treatments with bisphosphonates, steroidal and nonsteroidal anti-inflammatory drugs in the last 6 months were not enrolled in the study, as well as pregnant patients with acute periodontal cases and with less than 20 teeth in the mouth.

After recording clinical measurements, 4 periodontal affected sites were selected in each patient of both groups, one per quadrant, with a probing depth $\geq 6 \mathrm{~mm}$ and insertion loss $>3 \mathrm{~mm}$ in each patient. The area was isolated with cotton rolls, gently dried with air. If the patient had supragingival deposits, they were carefully removed with curettes. Samples of subgingival material were obtained by inserting two sterile absorbent paper cones standard No. 30 in the deepest part of the periodontal pocket for 20 seconds. Immediately after removing the sample, it was placed into a $1.5 \mathrm{ml}$ Eppendorf tube with sterile TE buffer solution (10 mM Tris- $\mathrm{HCl}, 1$ mM EDTA; $\mathrm{pH} 8$ ). The samples were transported at $4^{\circ} \mathrm{C}$ to the clinical microbiology laboratory for being immediately processed.

The tubes containing the samples were vortexed for 30 seconds and then subjected to boil for 5 minutes. Later, DNA extraction was performed using the Tissue DNA Kit (D3396-02 by E.Z.N.A http://goo.gl/BRuv) according to manufacturer's protocol.

The reference DNAs were obtained from the following strains: $C$. jejuni ATCC 33560, C. coli NLEP 1726, C. rectus ATCC 33238, C. concisus ATCC 33237, $C$. gracilis ATCC 33236 and $C$. ureolyticus NCTC 10941. DNA extraction was performed following the above-mentioned protocol.

Specific oligonucleotides were designed using bibliographic references and databases published in NCBI GenBank (Table 1). For each primer, a search was performed using the BLAST (Basic Local Alignment Search Tool) program in order to verify their specificity and rule-out possible crossed reactions with other oral species by comparing primer sequences (ALTSCHUL et al., 1997).

The molecular detection of Campylobacter species was performed using the KOD Hot Start DNA Polymerase kit (TB341) (Novagen, Germany, 2003 (http://goo.gl/L8zp0) following the instructions of the manufacturer. PCR amplicons were analyzed by $2 \%$ agarose gel electrophoresis in TBE $1 \mathrm{X}$ buffer. The gel was stained with $0.5 \mathrm{ug} / \mathrm{ml}$ ethidium bromide and visualized under ultraviolet light. Positive reactions were determined by the presence of bands of molecular size corresponding to species (Figure 1). 
Table 1. Oligonucleotides sequence, amplicon size, and specific gene target and reference used for selecting each primer.

\begin{tabular}{lccc}
\hline \multicolumn{1}{c}{ Oligonucleotides $\left(5^{`}-3^{\prime}\right)$} & Amplicon size $(\mathrm{pb})$ & Target gen & Reference \\
\hline Campylobacter spp. & 816 & 16S rRNA & $\begin{array}{c}\text { LINTON et } \\
\text { al., } 1996\end{array}$ \\
GGATGACACTTTTCGGGC & & &
\end{tabular}

Campylobacter rectus

TTTCGGAGCGTAAACTCCTTTTC

TTTCTGCAAGCAGACACTCTT

Campylobacter concisus

GGCTCAAAAGAGATCGCTCA

CCCTCAACAACGCTTAGCTC

Campylobacter gracilis

AACGGAATTTAAGAGAGCTT

CTTTCCCGATTTATCTTATG

Campylobacter ureolyticus

GAAGTAAAAAGAGGAATGGATAAAGAAGC

CTTCACCTTCAATATCCTCAGCAATAATTAAAAGA
598

16S DNA

ASHIMOTO

et al., 1996

555

Cpn60 gene CHABAN et

al., 2009

147

16S DNA

SIQUEIRA;

ROÇAS, 2003

540 hsp60 gene VANDAMME

et al., 2010

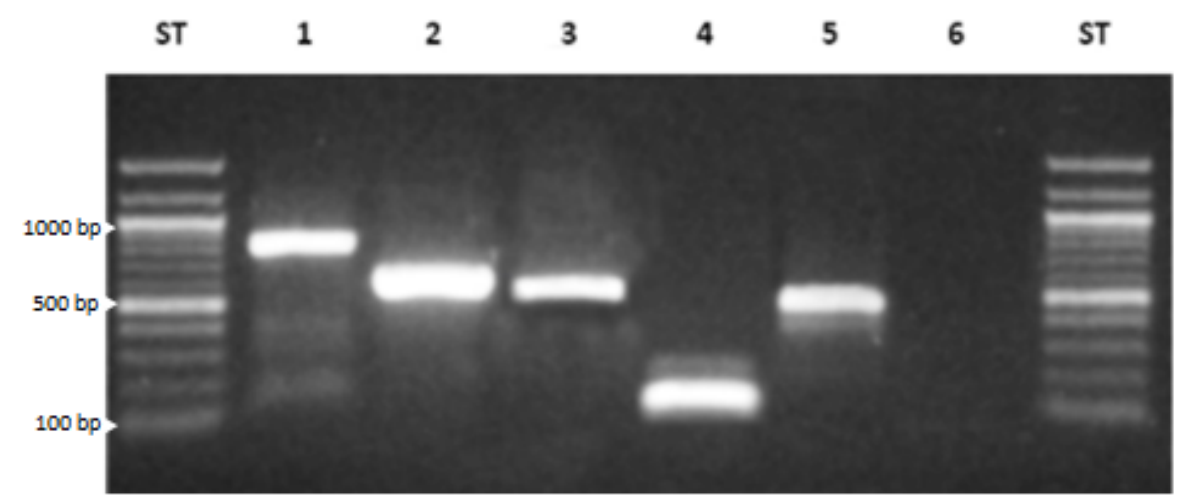

Figure 1. PCR electrophoretic analysis of positive samples. ST: standard molecular size; Lane 1: Campylobacter spp.; Lane 2: Campylobacter rectus; Lane 3: Campylobacter concisus; Lane 4: Campylobacter gracilis; Lane 5: Campylobacter ureolyticus; Lane 6: negative control.

Data were analyzed using descriptive and association statistics tests through the software SPSS Statistics 18 (IBM, Chicago, USA).

\section{RESULTS}

Subgingival crevicular fluid samples were taken from 30 patients ( 19 women and 11 men) with a mean age of 51.5 years, of whom 15 were smokers and 15 non-smokers. Demographic information and clinical parameters of the patients evaluated are summarized in Tables 2 and 3, respectively.

Campylobacter spp. frequency was high $(93.3 \%)$ being $C$. rectus to be the most prevalent species (80\%) followed by C. concisus (66.6\%), $C$. gracilis (33.3\%) and C. ureolyticus (10\%).

Campylobacter spp. showed a high prevalence in smoker patients with moderate to severe chronic periodontitis. Among these patients, the species $C$. rectus, $C$. concisus, $C$. gracilis and $C$. ureolyticus were found. In non-smoker patients, where $C$. gracilis was the least frequent one but $C$. ureolyticus was identified more frequently in nonsmoker patients with chronic periodontitis than in smokers, while $C$. gracilis showed statistically significant differences associated with the smoking habit (Table 4). 
Table 2. Patients distribution according to age and gender

\begin{tabular}{ccccc}
\hline & Age $^{\mathrm{a}}$ & Male $n(\%)$ & Female $n(\%)$ & Total $n(\%)$ \\
\hline Smokers & $52 \pm 7.6^{*}$ & $7(46.7)^{* *}$ & $8(53.3)^{* *}$ & $15(100)$ \\
Non-smokers & $51 \pm 5.9^{*}$ & $4(26.7)^{* * *}$ & $11(73.3)^{* * *}$ & $15(100)$ \\
\hline
\end{tabular}

${ }^{\mathrm{a}}$ Mean \pm standard deviation

* Not statistically significant $\mathrm{p}>0.05$ (p value 0.69 ); ** not statistically significant $\mathrm{p}>0.05$ ( $\mathrm{p}$ value 0.26 ); *** not statistically significant $\mathrm{p}>0.05$ ( $\mathrm{p}$ value 0.26 )

Table 3. Clinical parameters found in the evaluated patients

\begin{tabular}{lccc}
\hline \multicolumn{1}{c}{ Clinical parameters } & Smoker & Non-smoker & $p$ value \\
\hline Bleeding on probing & $59 \pm 27.41$ & $60.8 \pm 28.29$ & 0.444 \\
Pocket probing depth & $5.5 \pm 0.90$ & $5.4 \pm 0.49$ & 0.367 \\
Clinical attachment level & $8.44 \pm 3.05$ & $9 \pm 3.08$ & 0.352 \\
Pocket probing depth & $76.26 \pm 22.83$ & $70.89 \pm 24.83$ & 0.319 \\
\hline
\end{tabular}

Statistically significant $p<0.05$

Table 4. Campylobacter species found among smoker and non-smoker patients

\begin{tabular}{lccc}
\hline & \multicolumn{2}{c}{ Frequency } & Value of $p\left(\chi^{2}\right)$ \\
& Smokers $(\%)$ & Non-smokers $(\%)$ & Smokers v/s Non-smokers \\
\hline Campylobacter spp. & 100 & 86.7 & 0.143 \\
C. rectus & 93.3 & 66.7 & 0.068 \\
C. concisus & 73.3 & 60 & 0.439 \\
C. gracilis & 60 & 6.7 & $0.002^{\mathrm{a}}$ \\
C. ureolyticus & 6.7 & 13.3 & 0.543 \\
\hline
\end{tabular}

${ }^{a}$ Statistically significant $(p=<0.05)$

\section{DISCUSSION}

The results of this study indicated a high prevalence of Campylobacter spp. in the population under study. PCR analysis revealed the presence of the species $C$. rectus, $C$. gracilis, $C$. concisus and $C$. ureolyticus, while the presence of $C$. gracilis was found to be statistically significant in smoker patients with moderate to severe chronic periodontitis.

The clinical parameters of the patients did not show significant differences; smokers and nonsmokers had similar characteristics although a slight difference caused a plaque index with a lower rate in non-smokers. However, the evidence showed that there are no differences of plaque among smokers and non-smokers, suggesting that there is no association between the accumulation of plaque and oral hygiene of the patient (BERGSTRÖM, 2003; APATZIDOU et al., 2005).

The prevalence of $C$. rectus (80\%) was high and similar to the findings of RAMS et al., (1993). However, it exceeds the frequency reported by other authors (MACUCH; TANNER, 2000; KAMMA et al., 1999; GAJARDO et al., 2004). Nevertheless, all the studies mentioned, agree on that Campylobacter is the most frequent microorganism in chronic periodontitis.

C. concisus showed a prevalence of $66.6 \%$, which is higher than the one reported by KAMMA et al. (1999) and MACUCH and TANNER (2000). However, the detection of $C$. gracilis was low (6.7\%), but differed from the study of MACUCH and TANNER (2000), who reported a smaller occurrence of this pathogen. DUERDEN et al. (1987), found a prevalence of $6.7 \%$ of Bacteroides ureolyticus, later reclassified as $C$. urelolyticus (VANDAMME et al., 2010). These results are lower than those obtained in our investigation. Significantly, the prevalence of periodontal pathogens differs from one geographical area to another (HAFFAJEE et al., 2004; HERRERA et al., 2008), explaining the differences between the various studies.

We found a higher occurrence of Campylobacter spp. in smoker patients with chronic periodontitis than in non-smokers. $C$. gracilis showed a statistically significant difference in 
smokers, which was also observed by KAMMA et al. (1999) for $C$. concisus, $C$. rectus and $C$ gracilis. However, in our study, $C$. rectus and $C$. concisus showed no statistically significant differences, although they had a higher detection values in smokers than in non-smokers.

Reported evidences show that the smoker patients displayed a decrease of oxygen tension in the oral cavity, creating favorable environmental conditions in the periodontal pocket for the colonization of certain periodontopathogens (ABUSLEME et al., 2013; NICOLIĆ-JAKOBA et al., 2012). Therefore, it can be suggested that the oxygen conditions are important for $C$. gracilis, $C$. rectus and $C$. concisus and, in this oxygen reduced subgingival environment, they could increase the prevalence of $C$. gracilis for being a strict microaerobic microorganism (LASTOVICA, 2016).

C. urelolyticus was more frequently found in non-smokers patients and, even though there was no statistical difference, it is necessary to perform further studies to determine its prevalence in other geographical centers to contrast values and describe environmental conditions that could favor the colonization of this agent in the periodontal pocket.

Although the PCR provides a faster and more accurate molecular detection of microorganisms compared to the traditional culture methods of cultivation (ERICK; PFISTER, 2002), it fails to determine other characteristics of the identified species. Therefore, the combined use of traditional microbiological methods with molecular methods would allow performing additional monitoring of microbiological diagnosis for patients with periodontal diseases (LINTON et al., 1996).

This is the first study carried out in Chile, showing the prevalence of species of Campylobacter associated to chronic periodontitis. These results represent an advance and a contribution to the best knowledge about the agents of periodontitis in this geographical region, opening new paths and perspectives of association between the clinic and the laboratory. The association between the clinic and the laboratory, in addition to improving the etiological diagnosis of chronic periodontitis, will make it possible to establish programs for the control and prevention of this disease.

Our results demonstrated a high prevalence of Campylobacter in the analyzed population, showing an association between species of the genus Campylobacter and periodontal disease, suggesting that smoking is a risk factor for the association of $C$. gracilis with moderate and severe chronic periodontitis.

\section{ACKNOWLEDGMENTS}

This work was supported by Universidad Austral de Chile GRANT N 11 DID-PHIM-UACH

RESUMO: O objetivo deste estudo é identificar a presença de espécies de Campylobacter (C. rectus, C. concisus, C. gracilis e C. ureolyticus) em pacientes chilenos com periodontite crônica, e estabelecer a relação desses microrganismos com as condições periodontais de pacientes fumantes e não fumantes. Amostras de placa subgengival foram coletadas de quatro locais de tecido periodontal afetado de 15 pacientes fumantes e 15 não fumantes com periodontite crônica. Obteve-se uma amostra por quadrante, com profundidade de sondagem $\geq 6$ mm e perda de inserção $>$ $3 \mathrm{~mm}$ em cada paciente. A reação em cadeia da polimerase (PCR) foi realizada com os primers específicos 16S rDNA para a detecção molecular de C. rectus e C. gracilis, primers específicos de cpn60 para C. concisus e gene primers de hsp60 para C. ureolyticus. As espécies de Campylobacter apresentaram uma prevalência geral de 93,3\% nos pacientes periodontais, enquanto C. rectus foi o mais frequente (80\%), seguido por C. concisus (66,7\%), C. gracilis (33,3\%) e C. ureolyticus $(10 \%)$. Apenas C. gracilis apresentou associação estatisticamente significante $(\mathrm{p}=0,002)$ com a periodontite crônica entre as amostras de pacientes fumantes e não fumantes. Observou-se alta prevalência do gênero Campylobacter nas populações analisadas $(93,3 \%)$, sendo C. reto as espécies mais frequentes $(80 \%)$. Além disso, C. gracilis mostrou associação estatisticamente significante entre estado de fumante e periodontite crônica.

PALAVRAS-CHAVE: Campylobacter. Periodontite crônica. Fumantes. PCR.

\section{REFERENCES}

ABUSLEME, L.; DUPUY, A. K.; DUTZAN, N.; SILVA, N.; BURLESON, J. A.; STRAUSBAUGH, L. D.; GAMONAL, J.; DIAZ, P. I. The subgingival microbiome in health and periodontitis and its relationship with community biomass and inflammation. The International Society of Microbial Ecology Journal, v. 7, p. 1016-1025, 2013. https://doi.org/10.1038/ismej.2012.174 
ALTSCHUL, S. F.; MADDEN, T. L.; SCHÄFFER, A. A.; ZHANG, J.; ZHANG, Z.; MILLER, W.; LIPMAN, D. J. Gapped BLAST and PSI-BLAST: a new generation of protein database search programs. Nucleic Acids Research, v. 25, p. 3389-3402, 1997. https://doi.org/10.1093/nar/25.17.3389

APATZIDOU, D. A.; RIGGIO, M. P.; KINANE, D. F. Impact of smoking on the clinical, microbiological and immunological parameters of adult patients with periodontitis. Journal of Clinical Periodontology, v. 32, p. 973-983, 2005. https://doi.org/10.1111/j.1600-051X.2005.00788.x

ASHIMOTO, A.; CHEN, C.; BAKKER, I.; SLOTS, J. Polymerase chain reaction detection of 8 putative periodontal pathogens in subgingival plaque of gingivitis and advanced periodontitis lesions. Oral Microbiology Immunology, v. 11, p. 266-273, 1996. https://doi.org/10.1111/j.1399-302X.1996.tb00180.x

BERGSTRÖM, J. Tobacco smoking and risk for periodontal disease. Journal of Clinical Periodontology, v. 30, p. 107-113, 2003. https://doi.org/10.1034/j.1600-051X.2003.00272.x

CARVAJAL, P. Periodontal disease as a public health problem: The challenge for primary health care. Revista Clínica de Periodoncia, Implantología y Rehabilitación Oral, v. 9, p. 177 - 183, 2016.

https://doi.org/10.1016/j.piro.2016.07.001

CHABAN, B.; MUSIL, K. M.; HIMSWORTH, C. G.; HILL, J. E. Development of cpn60-based real-time quantitative PCR assays for the detection of 14 Campylobacter species and application to screening of canine fecal samples. Applied and Environmental Microbiology, v. 75, p. 3055-3061, 2009.

https://doi.org/10.1128/AEM.00101-09

CORETTI, L.; CUOMO, M.; FLORIO, E.; PALUMBO, D.; KELLER, S.; PERO, R.; CHIARIOTTI, L.; LEMBO F.; CAFIERO, C. Subgingival dysbiosis in smoker and non-smoker patients with chronic periodontitis. Molecular Medicine Reports, v. 15, p. 2007-2014, 2017.

https://doi.org/10.3892/mmr.2017.6269

DAHLÉN, G.; HASSAN, H.; BLOMQVIST, S.; CARLÉN, A. Rapid urease test (RUT) for evaluation of urease activity in oral bacteria in vitro and in supragingival dental plaque ex vivo. BMC Oral Health, v. 18, p. 89, 2018. https://doi.org/10.1186/s12903-018-0541-3

DARBY, I. B.; HODGE, P. J.; RIGGIO, M. P.; KINANE, D. F. Microbial comparison of smoker and nonsmoker adult and early-onset periodontitis patients by polymerase chain reaction. Journal of Clinical Periodontology, v. 27, p. 417-424, 2000. https://doi.org/10.1034/j.1600-051x.2000.027006417.x

DUERDEN, B. I.; GOODWIN, L.; O'NEIL T. C. Identification of Bacteroides species from adult periodontal disease. Journal of Medical Microbiology, v. 24, p. 133-137, 1987. https://doi.org/10.1099/00222615-24-2133

DZINK, J. L.; SOCRANSKY, S. S.; HAFFAJEE, A. D. The predominant cultivable microbiota of active and inactive lesions of destructive periodontal diseases. Journal of Clinical Periodontology, v. 15, p. 316-323, 1988. https://doi.org/10.1111/j.1600-051X.1988.tb01590.x

ERICK, S.; PFISTER, W. Comparison of microbial cultivation and a commercial PCR based method for detection of periodontopathogenic species in subgingival plaque samples. Journal of Clinical Periodontology, v. 29, p. 638-644, 2002. https://doi.org/10.1034/j.1600-051X.2002.290708.x

GAJARDO, M.; SILVA, N.; GÓMEZ, L.; LEÓN, R.; PARRA, B.; CONTRERAS, A.; GAMONAL, J.

Prevalence of periodontopathic bacteria in aggressive periodontitis patients in a Chilean population. Journal of Periodontology, v. 76, p. 289-294, 2004. https://doi.org/10.1902/jop.2005.76.2.289 
GAMONAL, J.; LÓPEZ, N.; ARANDA, W. Periodontal conditions and treatment needs, by CPITN, in the 3544 and 65-74 year-old population in Santiago, Chile. International Dental Journal, v. 48, p. 96-103. 1998. https://doi.org/10.1111/j.1875-595X.1998.tb00467.x

GEMMELL, M.; BERRY, S.; MUKHOPADHYA, I.; NIELSEN, H.L.; NIELSEN, H.; HOLD, G. L. Defining genome diversity of Campylobacter concisus between oral, faecal and colonic biopsy isolates. Gut, v. 66, p. 129, 2017. https://doi.org/10.1136/gutjnl-2017-314472.252

HAFFAJEE, A. D.; BOGREN, A.; HASTURK, H.; FERES, M.; LOPEZ, N. J.; SOCRANSKY, S. S. Subgingival microbiota of chronic periodontitis subjects from different geographic locations. Journal of Clinical Periodontology, v. 31, p. 996-1002, 2004. https://doi.org/10.1111/j.1600-051X.2004.00597.x

HENNE, K.; FUCHS F.; KRUTH, S.; HORZ, H. P.; CONRADS, G. Shifts in Campylobacter species abundance may reflect general microbial community shifts in periodontitis progression. Journal of Oral Microbiology, v. 6, p. 25874, 2014. https://doi.org/10.3402/jom.v6.25874

HERRERA, D.; CONTRERAS, A.; GAMONAL, J.; OTEO, A.; JARAMILLO, A.; SILVA, N.; SANZ, M.; BOTERO, J. E.; LEÓN, R. Subgingival microbial profiles in chronic periodontitis patients from Chile, Colombia and Spain. Journal of Clinical Periodontology, v. 35, p. 106-113, 2008.

https://doi.org/10.1111/j.1600-051X.2007.01170.x

KAMMA, J. J.; NAKOU, M.; BAEHNI, P. C. Clinical and microbiological characteristics of smokers with early onset periodontitis. Journal of Periodontal Research, v. 34, p. 25-33, 1999.

https://doi.org/10.1111/j.1600-0765.1999.tb02218.x

KINANE, D. F.; RADVAR, M. The effect of smoking on mechanical and antimicrobial periodontal therapy. Journal of Periodontology, v. 68, p. 467-472. 1997. https://doi.org/10.1902/jop.1997.68.5.467

LASTOVICA, A. Non-jejuni/coli Campylobacter species and related organisms in poultry, and their relevance in human and animal disease. In: Fonseca B., Fernandez H., Rossi D. (eds) Campylobacter spp. and Related Organisms in Poultry. Springer, Cham 2016. Chapter. 11, p. 185-206. https://doi.org/10.1007/978-3-319-29907$5 \_11$

LINTON, D.; OWEN, R. J.; STANLEY, J. Rapid identification by PCR of the genus Campylobacter and of five Campylobacter species enteropathogenic for man and animals. Research Microbiology, v. 147, p. 707-718, 1996. https://doi.org/10.1016/S0923-2508(97)85118-2

LOESCHE, W. S.; GUSBERTI, F.; METTRAUX, G. R.; HIGGINS, T.; SYED, S. Relationship between oxygen tension and subgingival bacterial flora in untreated human periodontal pockets. Infection and Immunity, v. 42, p. 659-667, 1983.

MACUCH, P. J.; TANNER, A. C. Campylobacter species in health, gingivitis, and periodontitis. Journal of Dental Research, v. 79, p. 785-792, 2000. https://doi.org/10.1177/00220345000790021301

MAHENDRAN, V.; RIORDAN, S. M.; GRIMM, M. C.; TRAN, T. A. T.; MAJOR, J.; KAAKOUSH, N. O.; MITCHELL, H.; ZHANG, L. Prevalence of Campylobacter species in adult Crohn's disease and the preferential colonization sites of Campylobacter species in the human intestine. Plos One, v. 6, p. e25417, 2011. https://doi.org/10.1371/journal.pone.0025417

MAN, S. M.; ZHANG, L.; DAY, A. S.; LEACH, S. T.; LEMBERG, D. A.; MITCHELL, H. Campylobacter concisus and other Campylobacter species in children with newly diagnosed Crohn's disease. Inflammatory Bowel Disease, v. 16, p. 1008-1016, 2010. https://doi.org/10.1002/ibd.21157

MEURIC, V.; LE GALL-DAVID, S.; BOYER, E.; ACUÑA-AMADOR, L.; MARTIN, B.; BING FONG, S.; BARLOY-HUBLER, F.; BONNAURE-MALLET, M. Signature of microbial dysbiosis in periodontitis. Applied and Environmental Microbiology, v. 83, p. e00462-17, 2017. https://doi.org/10.1128/AEM.0046217 
MIRA, A.; SIMON-SORO, A.; CURTIS, M.A. Role of microbial communities in the pathogenesis of periodontal diseases and caries. Journal of Clinical Periodontology, v. 44, p. S23-S38, 2017. https://doi.org/10.1111/jcpe.12671

MUKHOPADHYA, I.; THOMSON, J. M.; HANSEN, R.; BERRY, S. H.; EL-OMAR, E. M.; HOLD, G. L. Detection of Campylobacter concisus and other Campylobacter species in colonic biopsies from adults with ulcerative colitis. Plos One, v. 6, p. e21490, 2011. https://doi.org/10.1371/journal.pone.0021490

NIKOLIĆ-JAKOBA, N.; VOJNOVIĆ, S.; PAVIĆ, A.; JANKOVIĆ, S.; LEKOVIĆ, V.; VASILJEVIĆ, B. Polymerase chain reaction in the identification of periodontopathogens - a reliable and satisfactory method? Archives of Biological Sciences, v. 64, p. 1413-1423, 2012. https://doi.org/10.2298/ABS1204413J

PÉREZ-CHAPARRO, P. J.; GONÇALVES, C.; FIGUEIREDO, L. C.; FAVERI, M.; LOBÃO, E.; TAMASHIRO, N.; DUARTE, P.; FERES, M. Newly identified pathogens associated with periodontitis: a systematic review. Journal of Dental Research, v. 93, p. 846-858, 2014. https://doi.org/10.1177/0022034514542468

RAMS, T. E.; FEIK, D.; SLOTS, J. Campylobacter rectus in human periodontitis. Oral Microbiology Immunology, v. 8, p. 230-235, 1993. https://doi.org/10.1111/j.1399-302X.1993.tb00565.x

SHCHIPKOVA, A. Y.; NAGARAJA, H. N.; KUMAR, P. S. Subgingival microbial profiles of smokers with periodontitis. Journal of Dental Research, v. 89, p. 1247-1253, 2010.

https://doi.org/10.1177/0022034510377203

SIQUEIRA, J. F.; RÔÇAS, I. N. Campylobacter gracilis and Campylobacter rectus in primary endodontic infections. International Endodontic Journal, v. 36, p. 174-180, 2003. https://doi.org/10.1046/j.13652591.2003.00636.x

SRINIVASAN, P. C. The emerging role of epigenetics in the pathogenesis of periodontitis. A review. South African Dental Journal, v. 71, p. 26 - 33, 2016.

TOMAS, I; CAMELO-CASTILLO, A; BALSA-CASTRO, C; CASTELLANO, A; NOVOA, L; MIRA, A. New model of pathogenesis of chronic periodontitis: from infectious disease to polymicrobial dysbiosis.

Revista del Ilustre Consejo General de Odontólogos y Estomatólogos de España, v. 21, p. 131-145, 2016.

VANDAMME, P.; DEBRUYNE, L.; DE BRANDT, E.; FALSEN, E. Reclassification of Bacteroides ureolyticus as Campylobacter ureolyticus comb. nov., and emended description of the genus Campylobacter. International Journal of Systematic and Evolutionary Microbiology, v. 60, p. 2016-2022, 2010. https://doi.org/10.1099/ijs.0.017152-0

VANDAMME, P.; FALSEN, E.; POT, B.; HOSTE, B.; KERSTERS, K.; DE LEY, J. Identification of EF group 22 campylobacters from gastroenteritis cases as Campylobacter concisus. Journal of Clinical Microbiology, v. 27, p. 1775-1781, 1989.

VARGAS SEGURA, A. I.; ILYINA, A.; SEGURA CENICEROS, E. P.; SILVA BELMARES, Y.; MÉNDEZ GONZÁLEZ, L. Etiology and microbiology of periodontal diseases: A review. African Journal of Microbiology Research, v. 9, p. 2300-2306, 2015. 